\title{
"Intersección de procesos nacionales". Nacionalización y violencia política en el País Vasco, 1937-1978
}

\author{
Fernando Molina APARICIO \\ Universidad del País Vasco-Euskal Herriko Unibertsitatea \\ fernando.molina@ehu.es
}

Recibido: 08/05/2013

Aceptado: 10/06/2013

\section{RESUMEN}

En las décadas de 1960 y 1970 se produjo una intersección de procesos de nacionalización, uno de signo vasquista y el otro españolista. En ambos jugó un papel esencial la violencia. Ésta se había constituido en referente esencial del promovido por la dictadura, mediante la activación de políticas de memoria ancladas en la exaltación de la victoria en la Guerra Civil como mito fundacional del "Nuevo Estado". Sin embargo, en el tiempo en que este patriotismo guerrero comenzó a declinar fue cuando el nacionalismo vasco intensificó el suyo al completar su discurso belicista con el activismo armado. Este proceso nacionalizador ascendente se materializó en una primera fase simbólica, que buscó la destrucción del imaginario españolista. A partir de 1968 a esa fase sucedió otra más propiamente asesina, en la que la violencia se amplió a los individuos que representaban esa memoria, intensificándose este proceso diez años después, en plena transición democrática. La memoria abertzale recorrió, así, un camino muy diferente de que definió la memoria colectiva que inspiró el proceso de transición democrática en España.

Palabras clave: España, País Vasco, Guerra Civil, franquismo, transición, nacionalismo español, nacionalismo vasco, violencia política.

\section{A Crossroad of National Processes. Nationalization and Political Violence in the Basque Country, 1937-1978}

\begin{abstract}
In the 1960s and 1970s Basque and Spanish nationalizing projects overlapped in the Basque Country, with violence exerting a major role in both of them. Franco's Dictatorship used violence as a prominent tool to promote policies of memory extolling the Civil War as the foundational myth of the "New State". But when this bellicose patriotism started to wane Basque nationalism created its own version with a belligerent discourse accompanied by a call to arms. This raising nationalistic project had a first and symbolic stage dedicated to destroy the Spanish imaginary. It then, since 1968, evolved into a new and violent phase characterized by the killing of prominent individuals who symbolized that memory. That campaign of violence intensified during the transition to Democracy, helping us to understand why the abertzale memory followed a different path from that of the collective memories recalled to support Spain's democratic transition.
\end{abstract}

Key words: Spain, Basque Country, Civil War, Francoism, Transition to Democracy, Spanish Nationalism, Basque Nationalism, Political Violence. 


\section{Referencia normalizada}

Molina Aparicio, Fernando (2013). "Intersección de procesos nacionales: Nacionalización y violencia política en el País Vasco, 1937-1978”. Cuadernos de Historia Contemporánea, 35, pp. 63-87.

Sumario: 1. Introducción: Memoria y nacionalización. 2. La renacionalización franquista: los caídos. 3. Intersección de procesos nacionales. 4. La destrucción de la memoria de los caídos. 5. El aniquilamiento de su memoria viva. 6. Conclusión.

"Los hombres son camaleones. En una sociedad sana, parecen sanos, en una enferma, como la nuestra, parecen enfermos. Y en realidad no son ni una cosa ni la otra. Son mero relleno."

(Carta de Helmuth von Moltke a su esposa, Alemania, 8 de noviembre de 1941)

Ha habido ¡vaya que si ha habido! Vencedores y Vencidos; ha triunfado la España, una, grande y libre; (...). Sobre los falsos ídolos, arrojados de sus pedestales por las bayonetas de nuestros soldados, se levantará el edificio del nuevo Estado.

(Jose María de Areilza, Discurso en el Teatro Coliseo Albia, 8 de julio de 1937).

El exterminio de los agentes de la desnacionalización es una obligación que la naturaleza demanda de todo hombre. Más vale vivir como hombres que vivir como bestias desnacionalizadas por España y Francia.

(Federico Krutwig (bajo seudónimo), Vasconia. Estudio dialéctico de una nacionalidad, Buenos Aires, 1962)

"Se necesita sangre y tiempo para hacer un pueblo"

(Jose Manoel Pagoaga Gallastegi "Peixoto", Punto y Hora de Euskal Herria, 1982)

\section{Introducción: Memoria y nacionalización}

Desde finales del pasado siglo, el repunte del género biográfico y la individualización de la historia social han alimentado una nueva historiografía del nacionalismo que ha sometido a revisión los postulados más funcionalistas del paradigma modernista y que ha rescatado al individuo de su posición de recipiente pasivo de la identidad nacional, reconvirtiéndolo en sujeto activo en la elaboración de esta. Esta evolución teórica fue, a su vez, inducida por el "giro cultural" ". En España también se vive este tiempo de cambio de paradigmas, en el que "el aire está dando la vuelta", si bien el éxito de la tesis del "nacionalismo banal" tiene mucho que ver con la capacidad seductora que aún ejerce la contemplación vertical de los procesos de nacionalización ${ }^{2}$. El franquismo y la transición democrática son, en todo caso, un periodo señalado a la hora de calibrar la idoneidad o no del "cambio de paradigma". Y es que la sociedad de este tiempo mostró que la efectividad con que la nación es asimilada socialmente

\footnotetext{
1 MOLINA APARICIO, Fernando: "La nación desde abajo. Nacionalización, individuo e identidad nacional", en Alejandro Quiroga y Ferran Archilés (eds.), "La nacionalización en España”, Ayer, nº 90 , vol. 2 (2013), pp. 39-63.

2 MOLINA APARICIO, Fernando y CABO VILLAVERDE, Miguel: "Donde da la vuelta el aire. Reflexions sobre la nacionalització a Espanya", Segle XX, nº 4 (2011), pp. 139-140.
} 
depende en gran medida de la voluntad de los individuos por apropiarse de ella y reformularla como parte de su narrativa personal, seducidos por el relato que consumen con el fin de dar sentido a su identidad ${ }^{3}$. Sin esto no puede comprenderse cómo naciones como la vasca o catalana, que habían carecido de un soporte institucional y político durante la dictadura, pudieron constituirse en referente de derechos políticos de una sustancial parte de los españoles, mayoritaria en los territorios en que luego fueron afirmadas de la mano del Estado de las Autonomías.

De las nuevas propuestas "horizontales" de comprensión de los procesos de nacionalización pueden tomarse ciertas reflexiones. Primera, que todos ellos actúan a través de tres esferas interdependientes: la pública, vinculada a las instituciones del Estado y a la opinión mediática "nacional"; la semipública, que afecta tanto a los espacios de socialización local como a aquellos que responden a segmentaciones de signo religioso, social o político; y la privada, de ámbito familiar o sentimental, que tiene como eje al individuo-ciudadano ${ }^{4}$. Éste se inserta en estas esferas y "experimenta" en ellas la nación como relato de identidad y repertorio de símbolos y mitos que le permiten concebirse como tal ciudadano e imaginarse como "nacional"s. Cuando la violencia se vincula a la nacionalización lo hace a través de todas estas esferas, sustancialmente en la pública y semipública. En ambos espacios su efecto es devastador pues subvierte el sentido integrador de los procesos liberales de nacionalización, reconvirtiéndolos en prácticas de imposición cultural, de persecución política e ideológica y de anulación de los derechos individuales. La violencia, además, introduce criterios trascendentes en un terreno secularizado como es el de la política liberal, condicionando la variada forma en que los individuos interactúan con la nación y contribuyendo a expulsarlos, en variables proporciones, de las dos primeras esferas, forzándolos a recluirse en la íntima, si no a desaparecer de todas ellas mediante prácticas genocidas, de represión y castigo de la disidencia o meramente terroristas.

La naturaleza histórica de los procesos de nacionalización convierte éstos en auténticos procesos de "renacionalización". Y es que una vez logrado un nivel generalizado de identificación de los individuos con una determinada nación, todo lo sucedido posteriormente es un proceso de sucesivas y competitivas renacionalizaciones en un sentido liberal o integrista, derechista o izquierdista, democrático o autoritario, marxista o liberal, estatal o sub-estatal ${ }^{6}$. Esas renacionalizaciones no tuvieron que ser complementarias por el mero hecho de que tuvieran un mismo referente de identificación (caso de España). Y es que una de las cuestiones más importantes aún por incidir en el análisis histórico es la abstracción inherente a términos como "nacionalismo" o "nacionalización", conceptos que sirven a los historiadores para integrar (y, en igual

\footnotetext{
3 MOLINA APARICIO, Fernando: "La nación desde abajo"..., p. 51.

4 QUIROGA, Alejandro: "La nacionalización en España. Una propuesta teórica", en Alejandro Quiroga y Ferran Archilés (eds.), "La nacionalización en España", Ayer, nº 90, vol. 2 (2013), pp. 17-38.

5 ARCHILÉS, Ferrán: “¿Experiencias de nación? Nacionalización e identidades en la España restauracionista (1898-c. 1920)", en Javier Moreno (ed.), Construir España. Nacionalismo español y procesos de nacionalización, Madrid, CEPC, 2007, pp. 127-130.

6 QUIROGA, Alejandro, "La nacionalización en España”..., p. 29
} 
medida, difuminar) procesos múltiples, muchas veces competitivos unos con otros, que pueden llegar a anularse, por mucho que tengan un mismo referente territorial ${ }^{7}$.

En este texto voy a trasladar estas nuevas concepciones sobre la nacionalización al País Vasco en el franquismo y los inicios de la transición. Tras explicar ciertas características del proceso nacionalizador franquista y sus potenciales concomitancias culturales con una parte de los "derrotados", me voy a centrar en la época en que entró en decadencia mientras que otro alternativo, el vasco, inició su pujanza social. Son los años que podemos enmarcar entre la fundación de ETA, 1958, y la aprobación de la Constitución de la democracia, 1978. En estos años el contacto que los vascos tuvieron con la nación se definió por dos movimientos nacionalizadores que se interceptaron en las tres esferas aludidas de la mano de la memoria y la violencia. Uno "desde abajo", liderado simbólicamente por ETA y capitalizado por el movimiento autonomista e independentista en los años de la transición democrática. Y otro vinculado a la dictadura, puesto en marcha "desde arriba" "desde abajo", pero que se fue encontrando sin estos últimos referentes al compás del cambio social.

En la intersección entre ambos procesos tuvo lugar una disputa por la memoria colectiva en la que medió la violencia insurgente contra la dictadura. Precisamente esta permite definir una de las claves que decantaron el triunfo de un proceso nacionalizador vasquista respecto de otro españolista: el relato guerrero que el primero formalizó de la mano de ETA, precisamente cuando el segundo había comenzado a prescindir de dichos componentes discursivos y a retirarlos del espacio público. A ésta fase simbólica siguió la destrucción de la memoria de la "españolidad" vasca mediante una estrategia de asesinato selectivo de quienes la simbolizaban. Este proceso permitió laminar, como había ocurrido antes con la República, una memoria patriótica considerada como "enemiga" a condición de poner las bases de un régimen de terror y coacción social que impulsó el proceso de nacionalización abertzale pero que dificultó su arraigo en una cultura política cívico-liberal.

\section{La renacionalización franquista: los caídos}

El estudio académico sobre el franquismo vasco es muy deficiente en cuantía de investigaciones y está metodológicamente retrasado en comparación con el de otros territorios así como geográficamente descompensado (los mejores trabajos se han hecho en Álava y Guipúzcoa, y el mayor número en la primera provincia). Por lo demás, políticamente se ha centrado en la comunidad nacionalista, fundándose en investigaciones de signo sociológico muy inducidas por la memoria del nacionalismo vasco. Todo esto hizo que estos estudios coincidieran en reforzar una narrativa que

7 MOLINA APARICIO, Fernando y CABO VILLAVERDE, Miguel: "Historiografia y nacionalització a Espanya. Reflexions finals", Segle XX, no 4 (2011), pp. 161-169; PICKEL, Andreas: Nationalism and Violence: a Mechanismic Explanation, Center for the Critical Study of Global Power and Politics, Working Paper CSGP 07/1, Trent University, sin fecha, pp. 4-8. 
incidía en presentar una sociedad "inmune" a las políticas de consenso de la dictadura, con el fin de explicar las razones del surgimiento de ETA ${ }^{8}$.

Esta historiografía, a fuerza de incentivar la singularidad de lo ocurrido en el País Vasco, ha alimentado un relato abstraído de las pautas de análisis que se siguen en otros territorios, anclado en el canon interpretativo de los años setenta y ochenta. Y éste establecía que el "código de guerra" tuvo que ser el eje de la "legitimación" del nuevo Estado, dado que ni siquiera la religiosidad podía ser efectiva en un territorio "en donde la Iglesia y la religión estaban fundamentalmente en el bando vencido"9. Este es el planteamiento aún hegemónico y el que transmite, por ejemplo, la única síntesis disponible sobre este periodo ${ }^{10}$.

Éste "código" era la única explicación que se aducía (y aduce) para la no manifestación pública de un disenso político que se interpreta como mayoritario y que se da por descontado si de lo que se habla es de la comunidad abertzale. Síntesis históricas recientes han superado los tópicos de la narrativa clásica: desde la (magnificada) represión franquista sobre la comunidad abertzale a la impermeabilidad de la sociedad vasca a los criterios de adaptación impuestos por la dictadura. No en vano una de las pocas investigaciones (curiosamente, inédita) sobre la cuestión ya señaló que la mayoría del personal local y provincial del nuevo Estado fue de extracción local ${ }^{11}$.

La nacionalización en el franquismo no se ha abordado de manera monográfica sino mediante estudios dispersos, centrados en una perspectiva vertical y fuertemente institucional, atenta a la evaluación de agencias nacionalizadoras (educación, cultura popular, clase política, administración, etc. $)^{12}$. Uno de los escasos ensayos que defienden una aproximación "desde abajo" plantea que el nacionalismo fue el elemento nuclear que unificó las familias políticas que cimentaron el nuevo régimen, y que tuvo "un papel fundamental dentro del conjunto de discursos y recursos legitimadores de la dictadura" ${ }^{13}$. Por descontado, esta hipótesis (orientada a pensar la "experiencia de nación" del tardofranquismo) no es operativa para una sociedad como la vasca, en la que hubo un nacionalismo que definió la "cultura y (consiguientes) políticas de la Victoria” y dos más (el español liberal-obrero y el católico vasco) que fueron derrotados y perseguidos. Pero la religiosidad sí pudo jugar un papel impulsor de cara a

8 PÉREZ AGOTE, Alfonso: La reproducción del nacionalismo. El caso vasco, Madrid, Siglo XXI, 1984; GURRUCHAGA, Ander: El código nacionalista vasco durante el franquismo, Madrid, Anthropos, 1985.

9 PÉREZ-AGOTE, Alfonso: La reproducción del nacionalismo..., p. 79. 88.

10 Caso de VILLA, Imanol: Historia del País Vasco durante el franquismo, Madrid, Sílex, 2009, pp. 61-

11 Me refiero a CALVO, Cándida: Poder y consenso en Guipúzcoa durante el Franquismo, 1936-1951, defendida en la Universidad de Salamanca, en 1994. Las dos síntesis más expresivas en este tono desmitificador son DE PABLO, Santiago: "De la Guerra Civil al Estatuto de Guernica (1937-1979)”, en Iñaki Bazán (dir.), De Túbal a Aitor. Historia de Vasconia, Madrid, La Esfera de los Libros, 2002, pp. 589-663; Jose Luis, DE PABLO, Santiago y RUBIO POBES, Coro, Breve historia de Euskadi. De los fueros a la autonomía, Madrid, Debate, 2012, pp. 192-203.

12 Un estado de la cuestión en NÚÑEZ SEIXAS, Xose Manoel: "Nacionalismo español y franquismo: una visión general”, en M. Ortiz de las Heras (ed.), Culturas políticas del nacionalismo español, Madrid, La Catarata, 2009, esp. pp. 26-30.

13 FUERTES, Carlos: "La nación vivida. Balance y propuestas para una historia social de la identidad nacional española bajo el franquismo", en Ismael Saz y Ferrán Archilés (eds.), La nación de los españoles. Discursos y prácticas del nacionalismo español en la época contemporánea, Valencia, PUV, 2012, p. 282. 
la integración de una porción de los derrotados en la "cultura de la Victoria". Ésta habría actuado como una "pasarela ideológica" que conectó a católicos vencidos con vencedores en el marco de una nueva nación que, de hecho, tuvo en ambos elementos (nacionalismo y religión) sus pilares ideológicos y culturales. La violencia pudo intervenir, por lo demás, en fomentar la reunión de todos los miembros del "pueblo de Dios" en la nueva comunidad "nacional católica". La identidad que definió a ésta funcionó como una suerte de camino gregario que siguió una mayoría de ciudadanos, fundamentalmente porque resultaba más gravoso quedar excluido de ella que integrarse plácidamente en sus convenciones y marcos simbólicos, especialmente cuando éstas eran compartidas por todos ellos ${ }^{14}$.

Una importante dimensión de la "renacionalización" franquista en el País Vasco tuvo lugar en el plano de la memoria. El recuerdo "oficial" de la Guerra Civil fue fijado por el Estado en el calendario conmemorativo, incorporándole un ceremonial de impronta nacionalcatólica que interactuó fluidamente con la memoria local y familiar, alentando un ritual de marcado acento fúnebre. Celebraciones eclesiales, misas de campaña, procesiones, congresos eucarísticos, rogativas, vía crucis, traslados de figuras religiosas mutiladas, jornadas de desagravio y purificación de edificios afectados por la "maldad roja"... Todo este repertorio movilizador sirvió para afirmar la condición nacional del "nuevo Estado", especialmente en su particular dimensión como "comunidad de sufrimiento y sacrificio" ${ }^{15}$. Esta memoria colectiva se fundó en la intolerancia como "programa de autorrealización nacional" ${ }^{16}$. De ahí que la "Cruzada" funcionara como el mito fundador que interactuaba con la identidad local. Las ruinas de los templos destruidos o los edificios donde los republicanos practicaron masacres se convirtieron en lugares de memoria y marcos privilegiados de las movilizaciones patrióticas. Mientras, los "caídos" y "excautivos" locales fueron expuestos en el espacio en donde tenía lugar la reunión política del ciudadano (la iglesia parroquial) con el fin de marcar el ejercicio del recuerdo local destinado a hacer "patria" ${ }^{17}$.

Este factor local es esencial para comprender el sentido de la memoria franquista y su penetración en la vida vasca de la posguerra. Por supuesto, sólo se recordó a una parte de los muertos en la contienda, los caídos "por Dios y por España". El recuerdo selectivo privilegió, ya de entrada, el relato fundacional de la dictadura y el "deber de intolerancia" de su nacionalismo. Si esto realzaba un proyecto político que no pretendía la integración sino la sumisión de los vencidos, su capacidad de inserción social residió en que estos "caídos" fueron emplazados en un universo local. Una investigación ya clásica demostró la integración de una parte importante de los insurrectos vascos del 18 de julio en una cultura católica y campesina, radicada en patrones de

14 FORTI, Steven, El peso de la nación. Nicola Bombacci, Paul Marion y Óscar Pérez Solís en la Europa de Entreguerras, tesis doctoral, Departamento de Historia Moderna y Contemporánea, Universidad Autónoma de Barcelona, 2011, pendiente de publicación; MOLINA APARICIO, "Afinidades electivas..."

15 LANGEWIESCHE, Dieter: La época del Estado-nación en Europa, Valencia, PUV, 2012, pp. 68-70.

16 Ibídem pp. 106-107.

17 MOLINA APARICIO, Fernando: “Afinidades electivas. Franquismo e identidad vasca”, en Xose Manoel Núñez y Stéphane Michonneau (eds.), Imaginarios nacionalistas en la España del siglo XX, Madrid, Casa de Velázquez, 2013, en prensa. 
signo local, clientelar, casticista e integrista ${ }^{18}$. Y todo esto es ampliable al recuerdo colectivo de los que "cayeron", reconvertidos en símbolo de la narrativa de martirio $\mathrm{y}$ renacimiento nacional del régimen.

Frente al caso de muchos de los vencidos, especialmente los implicados en la causa de la República, los "mártires por Dios y por España" disfrutaron de la ventaja de ser ubicados en espacios de sociabilidad pequeños (pueblos, aldeas, villas semiurbanas, etc.). Su recuerdo fue fijado por el ritual conmemorativo en forma de lugares de memoria (lápidas, estatuas, estelas, efigies, bustos, etc.) coronados por (o integrados en) cruces que fueron instaladas, las más de las veces, en los espacios centrales de la vida local: las iglesias parroquiales ${ }^{19}$.

La realidad social del cristianismo español (y, dada su impronta rural, más aún del vasco) estaba dominada por la parroquia. Ésta constituía el lugar central en la vida del individuo. En sus registros se consignaba su nacimiento, matrimonio y defunción; en su interior sagrado el católico se encontraba con los sacramentos que la convertían en el centro de su vida espiritual ${ }^{20}$. Y presidiendo la celebración de estos sacramentos, adornando el altar, reposaron en estos años banderas nacionales y estandartes de las diversas fracciones políticas que participaron en la pasada guerra y que mostraban un determinado vínculo con la localidad en cuya parroquia fueron emplazadas. Más aún, el párroco que dirigía este enclave sagrado era aquél que conducía la vida espiritual y evaluaba el comportamiento social de los individuos, aquél a quien habían acudido con el fin de obtener informes favorables para evitar o moderar la violencia punitiva de los vencedores y para respaldar cualquier gestión que requiriera de la participación del Estado. La parroquia constituía, pues, el primer eslabón del "ejército del bien" frente al "ejército del mal", imaginario que había sido exportado de la historia sagrada a la memoria nacional ${ }^{21}$. De ahí que los muros, internos o externos de sus iglesias fueran el lugar predilecto para colocar las estelas y lápidas que recordaban a los mártires locales, a los "caídos" de ese "ejército".

Durante las tres primeras décadas del nuevo siglo la parroquia había sido concebida por la Iglesia no como una división territorial o un conjunto de edificios religiosos, sino como una "pequeña cristiandad", concepción que se radicalizó en los años treinta, a medida que la atmósfera laicista impulsó a los católicos a refugiarse en ella con el fin de acordar cómo defenderla de los embates de la "República atea" 22 . Llegada la guerra y la posguerra, esta "pequeña cristiandad" se convirtió en metonimia de la "nación". Junto con la familia se convirtió en el símbolo de esta más cercano al individuo. De ahí que la renacionalización franquista no consistiera únicamente en una serie de políticas impuestas "desde arriba" sino que contara con un alto potencial de enraizamiento local. Los caídos eran personas conocidas en un universo en donde

18 UGARTE, Javier: La nueva Covadonga insurgente. Orígenes sociales y culturales de la sublevación de 1936 en Navarra y el País Vasco, Madrid, Biblioteca Nueva, 1998.

19 CASTRO, Luis: Héroes y caídos. Políticas de la memoria en la España contemporánea, Madrid, La Catarata, 2008, pp. 87-137.

20 PELLISTRANDI, Benoît: "La realidad social y antropológica del catolicismo y los orígenes religiosos de la Guerra Civil", en Jaume Aurell y Pablo Pérez (eds.), Católicos entre dos guerras. La historia religiosa de España en los años 20 y 30, Madrid, Biblioteca Nueva, 2006, pp. 128-129.

21 Ibídem, p. 137.

22 La "pequeña cristiandad" en Ibídem, p. 139. 
funcionaban hábitos de sociabilidad y comunidad fundados en el patronazgo y la tradición. Aquel que figuraba en la lápida colocada en la entrada de la iglesia o en el muro que flanqueaba el altar era una persona con rostro. No era un "soldado desconocido" abstraído en una lista de caídos, era un vecino cuya familia era conocida y que, en tanto que "mártir", compartía con la parroquia que lo honraba la gloria de la victoria al compás del calendario conmemorativo fijado por el nuevo Estado.

El impacto de este recuerdo no se reduce, sin embargo, al ámbito de la parroquia. Los monumentos que evocaban a los caídos propios y que reproducían simbólicamente los valores característicos de la narrativa fundadora del nuevo Estado (exclusión del vencido, exaltación del vencedor en su calidad de héroe y mártir) se emplazaron en otros muchos sitios, al compás de la definición de un nuevo urbanismo que también se convirtió en parte de la "cultura de la victoria" y que renombró calles y plazas, reconstruyó éstas ubicando en ellas estos monumentos y destruyó, a la par, cualquier lugar de memoria que pudiera recordar que había existido otra nación española alternativa. Todos estos monumentos llevaron incorporado el simbolismo de la cruz, en tanto eran concebidos como "monumentos a la muerte, que pretendían perpetuar la memoria de los excombatientes, de los caídos, de los que (...) se habían inmolado por la salvación de la nación, los que se habían sacrificado por los que todavía vivían. (...) Nada mejor que la cruz para simbolizar (...) el carácter ejemplificador y útil de su sacrificio... pero también su resurrección y salvación" ${ }^{23}$.

La versatilidad y enraizamiento local de este recuerdo monumental ha sido estudiado en la ciudad de Bilbao a través del caso de los doscientos veinticinco asesinados por milicianos incontrolados en ella en la sangrienta jornada del 4 de enero de 1937. Esta fecha se convirtió en una de las más señaladas del calendario conmemorativo local, en el marco de la conversión de la contienda en el mito fundacional del nuevo régimen ${ }^{24}$. De ahí que en Bilbao la jornada adoptara un tinte excepcional en el marco del calendario conmemorativo patriótico, formado por la conmemoración de los caídos, de los Mártires de la Tradición o las festividades del 18 de julio, de la "liberación" de la villa, etc. Todas estas conmemoraciones incorporaron cortejos fúnebres que recorrían los lugares en que se cometieron los crímenes de octubre de 1936 o enero de 1937 y finalizaban en la cripta-mausoleo y el monumento en memoria de sus víctimas ${ }^{25}$.

La pervivencia de estos lugares de memoria y su contribución al sostenimiento de un relato institucional que convertía a los caídos en "mártires" de España dependió de una comunidad social, afectiva, que se encargó de promover el recuerdo, de gestionarlo y de perpetuarlo. Las delegaciones de excautivos de cada provincia, las hermandades de excombatientes y las secciones locales del Movimiento Nacional participaron, junto con la Iglesia, en esa tarea, en un programa de conmemoraciones

23 DEL ARCO, Miguel Ángel: "Las cruces de los caídos: instrumento nacionalizador en la «cultura de la victoria»", en Jorge Marco, Carlos Fuertes, Claudio Hernández y Miguel Ángel del Arco (eds.), No solo miedo. Actitudes políticas y opinión popular bajo la dictadura franquista (1936-1977), Granada, Editorial Comares, 2013, (en prensa) [agradezco al autor su consulta].

24 AGUILAR, Paloma: Politicas de la memoria y memorias de la política, Madrid, Alianza, 2008, p. 99

25 LANDA, Carmelo: "Bilbao, 4 de enero de 1937. Memoria de una matanza en la Euskadi autónoma durante la Guerra Civil española”, Bidebarrieta, vol. 18, (2007), pp. 79-115. 
que reunieron periódicamente a miles de ciudadanos en Bilbao o San Sebastián, y a la práctica totalidad de los habitantes de las localidades más pequeñas. Por ello insisto que por debajo de la nacionalización vertical existió otra de signo horizontal, practicada en el marco de la esfera semipública (hermandades de excombatientes, parroquias, iglesias, cofradías religiosas, cuadrillas de amigos) y de la privada-familiar. Los testimonios de presos y combatientes y las semblanzas de los mártires y caídos llenaron de contenido cotidiano la prensa, alimentaron folletos y libros, nombraron el callejero urbano y las iniciativas escultóricas locales y nutrieron los exordios y exaltaciones de los sermones parroquiales y discursos institucionales en los años 40 y $50^{26}$.

\section{Intersección de procesos nacionales}

En los años sesenta, este tipo de políticas del recuerdo comenzaron a fosilizarse al cambiar el canon narrativo del régimen, que comenzó a adoptar un sentido más neutro, centrándose en la paz y difuminando el componente de victoria ${ }^{27}$. En los años del desarrollismo tuvo lugar un declive del "discurso fuerte" de nación, que fue sustituido por otro centrado en la España "diferente y optimista". Se ha interpretado como un intento de buscar una mayor conexión entre el discurso de la nación y el de una ciudadanía despolitizada, en la que una nueva generación joven y dinámica carecía de memoria personal de la guerra y buscaba un relato del pasado menos sectario ${ }^{28}$. La narración épica y maniquea entró en crisis y fue cobrando fuerza en el discurso público y el ceremonial patriótico la apelación a la guerra con un significado más trágico e integrador. Esta transformación fue oportunista y, cuando fue necesario, la narrativa de la "Victoria" volvió a reproducirse ${ }^{29}$.

Surgió, en todo caso, en ciertos ámbitos minoritarios un nuevo relato que cuestionaba la "legitimidad de origen" de la dictadura y sus tonos guerreros. Fue impulsado especialmente desde posiciones intelectuales y políticas católicas aperturistas, e interactuaba con el que, desde posiciones antifranquistas, impulsó la política de "reconciliación nacional" del Partido Comunista. Una nueva generación de hijos de vencedores y vencidos se unió a una generación de padres descreídos de la dictadura y comenzó a recusar la narrativa nacional franquista, inaugurando un lenguaje político integrador fundado en nuevos valores (democracia, amnistía, ciudadanía, libertad). El nuevo proyecto político democrático "interno" requirió de un nuevo recuerdo colectivo centrado en una figura narrativa: la reconciliación ${ }^{30}$. Ésta "vino a ser, pues, como un relato que liquidaba todos los grandes relatos. A partir del momento en que opositores y disidentes sólo pudieron encontrarse hablando un lenguaje de democracia, la razón del gran relato, fuera cual fuese, se disolvió en el aire". Ese "gran relato"

26 Es la misma tesis que propone DEL ARCO, Miguel Ángel: "Las cruces de los caídos”...

27 AGUILAR, Paloma: Políticas de la memoria ..., p. 114.

28 FUERTES, CARLOS: "La nación vivida", p. 284.

29 CASTRO, Luis: Héroes y caídos..., pp. 133-134.

30 JULIÁ, Santos: "De «Guerra contra el invasor» a «Guerra fratricida»", en Santos Juliá (Coord.), Victimas de la Guerra Civil, Madrid, Temas de Hoy, 1999. pp. 43-47 
era el de la nación franquista y, en efecto, el cambio en el recuerdo de la guerra simbolizó su crisis en estos años ${ }^{31}$.

En el País Vasco, el cambio social, la llegada masiva de inmigrantes, la secularización abrupta y la industrialización y urbanización aceleradas transformaron la propia cartografía del recuerdo público. Lo recordado siempre va intrínsecamente asociado a un paisaje y a una cultura que se encarga de dotarle de significado nacional ${ }^{32}$. Y en el País Vasco de los 60 y 70 este paisaje y cultura se transformaron radicalmente. El convento de El Carmelo de Bilbao donde se había producido una de las masacres de presos políticos del 4 de enero de 1937 fue rodeado, a finales de los sesenta, de enormes bloques de hormigón y ladrillo que alojaban enjambres de trabajadores, la mayoría inmigrantes, que arrasaron las huertas y pequeños caseríos e importaron sus propios recuerdos, que carecían de vínculo alguno con el trauma allá vivido años antes e incorporaban uno más propio: el de la pérdida de sentido vital del campesino en un paisaje ajeno como era el industrial.

Surgió un nuevo País Vasco, el país de la urbanización "geocida" a que se refería Julio Caro Baroja, de enormes flujos inmigrantes llegados a poblar los mismos espacios continentales y costeros donde el tradicionalismo católico había ido reproduciéndose desde los inicios de la revolución liberal. Un país abruptamente secularizado, con una nueva Iglesia de jóvenes implicados en el horizonte reformador del Vaticano II y entusiastas, como muchos de sus feligreses, de nuevos dioses seculares (la clase obrera, la nación vasca), que emplearon como canalizadores (si no sustitutivos) de una divinidad cada vez más difícil de incorporar a su experiencia íntima. Un país en el que la imposición pública de una moralidad religiosa conculcadora de derechos y libertades individuales fue perdiendo sentido entre sus habitantes más jóvenes, muchos de ellos secularizados. Transformado el marco rural en que el catolicismo tradicionalista se había reproducido sociológicamente, falta de orientación política y social su religiosidad integrista que había articulado culturalmente a los simpatizantes de la insurrección militar de julio de 1936, secularizada la vida pública por efecto de la urbanización e industrialización, el franquismo vasco comenzó a desaparecer sociológicamente ${ }^{33}$.

La cultura política de este franquismo (compuesta de fascismo, tradicionalismo católico, regionalismo provincialista, nacionalismo oposicional e ideal contrarrevolucionario), alimentada por una narrativa heroica y apocalíptica, imbuida de religiosidad, carecía de sentido en una sociedad modernizada y secularizada. Los alcaldes más representativos de los grandes municipios carlistas (Baracaldo, Durango, Bergara, Azpeitia, Tolosa) fueron sustituidos en estos años por tecnócratas con una actitud diferente ante el pasado, desconectada de lo que la "Tradición" había significado para la clase política implicada en el golpe del 18 de julio. Y mientras esto ocurría, el

31 JULiÁ, Santos: Historias de las dos Españas, Madrid, Taurus, 2005, p. 462.

32 CASTIÑEIRA, Ángel: "Naciones imaginadas. Identidad personal, identidad nacional y lugares de memoria”, en J. R. Resina y U. Winter (eds.), Casa encantada. Lugares de memoria en la España constitucional (1978-2004), Barcelona, Verduert, 2005, pp. 54-56

33 MOLINA APARICIO, Fernando: "De la historia a la memoria. El carlismo y el problema vasco (19681978)", en El carlismo en su tiempo: geografias de la contrarrevolución, Pamplona, Gobierno de Navarra, 2008, pp. 190-191. 
nacionalismo vasco crecía impulsado por una juventud que lo convirtió en cauce de comunicación intergeneracional, en tanto que opción que contaba con el carisma de haber sido "antifascista" y, a la par, de haber mantenido una tradición que ahora se veía dúctil a las nuevas modas ideológicas y políticas impulsadas por el marxismo.

Las afinidades entre la cultura de la derecha católica que respaldó la insurrección del 18 de julio de 1936 y la del nacionalismo vasco conservador que se posicionó en contra, explican la acomodación al "nuevo Estado" de la memoria abertzale (frente al caso de la republicana, que fue laminada, como lo fueron sus respaldos sociales), instalada en el marco de la esfera semipública (asociaciones religiosas, culturales y deportivas) y privada (familia). Esta memoria reprodujo la misma narrativa franquista, fundada en referentes de orgullo nacional, causa sagrada, trauma colectivo y ánimo de revancha. Una memoria que se explica por ser la propia de vencidos cómodamente reubicados en la comunidad de vencedores. Una memoria como "imperativo categórico" diferente a la de los "rojos", que a partir de la aceptación de su derrota total había evolucionado a un "olvido activo" que impulsó, en buena medida, la cultura de la futura transición democrática ${ }^{34}$.

Así, mientras los parámetros épicos, belicistas y revanchistas de la memoria franquista empezaron a verse solapados a otros referentes (Paz, Prosperidad, Modernidad) tuvo lugar el resurgimiento de un movimiento nacionalista vasco cuyo discurso acerca del pasado no se había movido un ápice del de la propaganda bélica: la guerra como producto de una invasión española con la que los vascos no colaboraron; el franquismo como una cultura política alienígena (en tanto que fascismo), traída por españoles invasores; la guerra como un instrumento para el genocidio de los vascos, simbolizado en la villa mártir de Guernica. Y todo ello colocado como parte de una cadena épica que enlazaba con las guerras carlistas y la lucha milenaria del "pueblo vasco" en pos de la independencia nacional ${ }^{35}$.

Esta trama narrativa es la que ETA asumió en sus elaboraciones doctrinales y la que sus miembros adoptaron como relato personal, identificando su suerte con la de los luchadores nacionalistas en la guerra y flirteando con el ideal del martirio por la patria. En 1963, uno de sus líderes más importantes, Txabi Etxebarrieta, había escrito un poema en el que imaginaba su muerte en lugares en los que se habían librado combates durante la pasada guerra, identificándose con los "gudaris" allí caídos. La revancha permeaba el relato del pasado del nuevo nacionalismo vasco. Cuando este joven muriera en un enfrentamiento armado cinco años después, tras haber asesinado poco antes a un guardia civil en nombre de "Euskadi", fue convertido por esta co-

34 MOLINA APARICIO, Fernando: "Lies of Our Fathers"... El recuerdo compartido de los herederos de los republicanos y su transformación en narrativa nacional de la transición, en JULIÁ, Santos: "Echar al olvido: Memoria y amnistía en la transición a la democracia en España”, en J. C. Davis e Isabel Burdiel (eds.), El otro, el mismo. Biografia y autobiografia en Europa, siglos XVI-XX, Valencia, PUV, 2005, pp. 347370. Coincide con prácticas sociales que se han considerado más "sanadoras" que las que se refugian en la "memoria como imperativo categórico": RIEFF, David: Against Remembrance, Melbourne, University of Melbourne Press, 2011, p. 127.

35 FERNÁNDEZ, Gaizka: Héroes, heterodoxos y traidores. Historia de Euskadiko Ezkerra, 1974-1994, Madrid, Tecnos, 2013, pp. 46-48.; DE PABLO, Santiago: "Guerra Civil", 447-448, 450-451; MURO, Diego: "The politics of war memory in radical Basque nationalism", Ethnic and Racial Studies, vol. 32, no 4 (2009), pp. 659-678. 
munidad política en lo que había aspirado a ser en ese poema: un nuevo gudari que recogía el testigo patriótico dejado por los caídos tres décadas antes. En 1964, ETA había recordado, en uno de sus textos propagandísticos, a "los gudaris de todos los tiempos que ofrendaron su vida por la independencia de Euzkadi. En especial, los de la guerra 36/37", de los que sus activistas se consideraban herederos. En 1965, tuvo lugar la primera jornada conmemorativa en memoria de estos luchadores, el "Gudari Eguna". No fue convocada por ETA sino por el Gobierno Vasco en el exilio y reunió a antiguos gudaris del PNV con jóvenes aspirantes a tal condición, simpáticos a los ideales de ETA. Se reunieron en lugares similares a los que Etxebarrieta había evocado. Demasiadas coincidencias que muestran que existía una atmósfera "mnemónica" que estaba preparando narrativamente el derramamiento de sangre que pronto iba a tener lugar. En unas hojas volantes distribuidas por el PNV con motivo de esa celebración el ejemplo de los gudaris caídos fue reivindicado como "aliento de los que siguen en lucha, [y] la incorporación de los que aún no están en ella"36.

El "gudarismo", la exaltación del militarismo abertzale como tradición legitimadora de la particular "guerra" que una nueva generación pretendía librar contra la dictadura, fue el relato esencial de la narrativa del recuerdo que alimentó la nueva "liturgia mnemónica" del nacionalismo vasco radical. Pero la clave reside en que ésta no era privativa de esta sección de la comunidad abertzale, sino de la totalidad de ella. No hubo transición en esta comunidad a un discurso conciliador, como ocurrió en el caso de los llamados "rojos". El canon narrativo violento se mantuvo incólume y alimentó el discurso y la práctica política de una nueva generación que se autorrepresentó como una peculiar "Resistencia" antifascista, asimilando esta memoria a nuevos influjos ideológicos (marxismo, anticolonialismo, etc. ${ }^{37}$.

Este relato contribuyó a suplir el silencio que muchos "gudaris" habían adoptado respecto del trauma que habían vivido. Su "recuerdo común" no cuestionó el "recuerdo compartido" de la contienda de las generaciones de nacionalistas vascos que coincidieron en estas décadas de 1950 y $1960^{38}$. La transmisión de un recuerdo personal forzosamente subjetivo hubiera ayudado a cuestionar los mitos propagandísticos abertzales tan afines a los franquistas en su común fundamento en figuras maniqueas, de martirio y épica, adoptadas mediante tropos narrativos como la metonimia (la causa del Gobierno Vasco como causa propia de "los vascos") o la sinécdoque (la figura de los gudaris como representativa de la de "todos" los vascos combatientes). Sin embargo, la suplantación del relato personal por el grupal permitió que se mantuviera incólume un repertorio narrativo sobre la guerra formalizado en la esfera íntima, a través de las "historias (de) nacionalistas" que se transmitían en ella ${ }^{39}$.

\footnotetext{
36 CASQUETE, Jesús: “Txabi Etxebarrieta”, en Santiago de Pablo y otros (coords.), Diccionario ilustrado de símbolos del nacionalismo vasco, Madrid, Tecnos, 2012, p. 276, "Gudaris", en ibídem, p. 432.

37 FERNÁNDEZ, Gaizka: Héroes, heterodoxos y traidores. pp. 46-48. CASQUETE, Jesús: En el nombre de Euskal Herria. La religión politica del nacionalismo vasco radical, Madrid, Tecnos, 2009: 135-177; MURO, "The politics of war memory"..., p. 669.

38 LIES of our fathers ...; MARGALIT, Avishai: Ética del recuerdo, Barcelona, Herder, 2002.

39 MOLINA APARICIO, Fernando, "Lies of our fathers"...; QUIROGA, Alejandro: "La nacionalización en España", pp. 26-28; NUÑEZ SEIXAS, Sobre memoria, minorías nacionales y nacionalismos sin estado», en F. Gómez (ed.), El derecho a la memoria, Zarautz, Diputación Foral de Gipuzkoa, 2006, pp. 451-452; JUARISTI, Jon: El bucle melancólico. Historias de nacionalistas vascos, Madrid, Espasa, 1997, pp. 18-20;
} 
Así, en la opción que la nueva generación abertzale hizo por la violencia política tuvo un peso fundamental una "cultura de derrota" fomentada en la esfera familiar pero que alimentó también la semipública durante las décadas de 1950 y 1960 (parroquias, asociaciones deportivas, montañeras y juveniles, cuadrillas de amigos y estudiantes). En ambos espacios tuvo lugar una "renacionalización" abertzale alimentada por un recuerdo revanchista, fundado en mitos como el de Guernica, la "villa mártir" que reflejaba el genocidio de unos "vascos" identificados con la militancia abertzale vencida, cuya represión resultaba magnificada al no encontrar contraste alguno con una memoria republicana disuelta por la violencia estatal implacable de la guerra y la posguerra ${ }^{40}$.

Si la violencia fue, para los jóvenes etarras de estos años, "una pantalla en blanco en la que cada cual tenía el derecho a proyectar sus propios fantasmas", esos fantasmas fueron convocados por una memoria oficial reformulada desde posiciones de signo marxista-leninista y anticolonial ${ }^{41}$. En esa memoria lo que se olvidaba era tan importante como lo que se recordaba de manera que, como en el caso de Mario Onaindia, los sufrimientos de un padre asimilado a los mitificados gudaris alimentaban el anhelo de venganza del hijo a la hora de apuntarse a esa suerte de "Resistencia vasca" descontextualizada que representó la ETA de esos años ${ }^{42}$.

Esta memoria colectiva formó parte de la adecuación del nacionalismo vasco al nuevo ciclo de protesta política y social contra la dictadura a cuyo frente se puso ETA a partir de 1968. Y es que el relato del pasado que alimentó el recuerdo compartido abertzale vinculaba los asesinatos y represalias de la guerra, magnificados y recordados selectivamente, con los nuevos actos represivos que las acciones de ETA generaron: las muertes de activistas y de ciudadanos inocentes en episodios de violencia policial, las redadas policiales masivas, la tortura sistemática de los detenidos, los estados de excepción, la ocupación del espacio público por efectivos policiales apresuradamente importados de fuera del País Vasco. Se trataba de una memoria útil con la que recordar un pasado no vivido a partir de la experiencia del presente, dotando a ésta (y a los que la protagonizaban) de un sentido (nacional) sagrado, épico $\mathrm{y}$ trascendente ${ }^{43}$.

Ésto es lo que explica por qué un joven inmigrante pudo sentirse tentado a implicarse en la lucha armada de ETA y hacer suya una memoria que no era "común" a él pero sí "compartida" por él. Una memoria con la que, además, podía rellenar el silencio familiar sobre la guerra practicado por su padre, (de origen vasco y militancia republicano-socialista) represaliado tras la guerra, dando también con un hilo de continuidad entre su lucha y la de éste, entre su identidad personal y la memoria familiar. Este antiguo militante de ETA ha recordado cómo el "voluntarismo que creíamos revolucionario era hijo de la misma cultura nacional católica que nos habían incul-

\footnotetext{
40 MOLINA APARICIO, Fernando, "Lies of our fathers"...

41 ONAINDIA, Mario: Guía para orientarse en el laberinto vasco, Madrid, Temas de Hoy, 2003, p. 212.

42 MOLINA APARICIO, Fernando: Mario Onaindia (1948-2003). Biografia patria, Madrid, Biblioteca Nueva, 2012, pp. 82-87.

43 MOLINAAPARICIO, Fernando: "Lies of our fathers"...; AGUILAR, Paloma: "La guerra civil española en el discurso nacionalista vasco. Memorias peculiares, lecciones diferentes", J. Ugarte (ed.), La transición en el País Vasco y España. Historia y memoria, Bilbao, UPV, 1998, p. 137.
} 
cado y nos había convertido en (...) bastardos del propio régimen. Nuestro lenguaje y comportamientos eran los mismos de nuestros enemigos" 44 . Y eran "los mismos" porque estaban guiados por una misma forma de recuerdo inspirada en la común cultura católica que había alimentado a ambos nacionalismos. De ahí que el mismo afán que el franquismo se aplicó en destruir la memoria de la comunidad republicana lo abrazara este nuevo nacionalismo vasco en hacer lo propio con la franquista.

\section{La destrucción de la memoria de los "caídos"}

Cualquier recuerdo compartido por una comunidad que se proclama nacional tiende a ir vinculado a una tradición. Es un recuerdo cerrado, que fija la única versión del pasado aceptada por el canon narrativo de la nación. Por ello apelará al creer más que al saber. La alta significación de su relato empujará a la comunidad a convertirlo en una experiencia de vida para los "creyentes", en un elemento revivificador, en el sentido de que da vida al recuerdo y, consiguientemente, a los antepasados idealizados ${ }^{45}$. Esta revivificación es esencial en cualquier "renacionalización", especialmente en un contexto de cambio social. Tal es el sentido que tuvieron determinadas prácticas simbólicas que precedieron y acompañaron la violencia etarra.

A partir de 1967, la dirección de ETA atacó sistemáticamente los lugares de memoria del franquismo vasco con el fin de destruir el imaginario de una patria que consideraba ajena a los vascos. Esa destrucción formaba parte de uno de los principios fundamentales que adoptó la organización: "regenerar" una patria que consideraba que había entrado en un proceso de decadencia nacional por efecto de las transformaciones sociales y económicas ocurridas en esos años y por la acción "genocida" de la dictadura y sus políticas de nacionalización ${ }^{46}$. Regeneración, revivificación y renacionalización compusieron un mismo programa político plasmado en la destrucción de los lugares de memoria de la nación "enemiga".

Se ha subrayado ampliamente la contextualización de estos hechos en una determinada "violencia de resistencia" que pretendía dar testimonio de la existencia de una contestación política y nacional a ésta. Menos se ha subrayado, en cambio, que toda actividad "resistente", por muy delirante que resulte, utiliza la violencia y la intimidación como parte de un lenguaje político cuyo objetivo es la "utopía nacional"47. Es más, el propio contenido revolucionario, "antifranquista" y anticolonial no constituyeron sino canales con que manifestar un proyecto nacionalizador. Un proyecto que no tenía que ser compartido por la generalidad de la militancia ni ser el fin fundamental del discurso que ésta elaboraba en tanto que "organización". Bastaba con que fuera presentado como tal por los intelectuales que ubicaron sus acciones en la

44 URIARTE, Teo: Mirando atrás. De las filas de ETA a las listas del PSE, Barcelona, Ediciones B, 2005, pp. 60,67

45 MARGALIT, Avishai: Ética del recuerdo...

46 JÁUREGUI, Gurutz: Ideología y estrategia política de ETA. Análisis de su evolución entre 1959 y 1968 , Madrid, Siglo XXI, 1981, pp. 139-143.

47 FARALDO, Jose María: La Europa clandestina. Resistencias a las ocupaciones nazi y soviética, 19381948, Madrid, Alianza, 2011, pp. 42-44. 
narrativa de nación, colocándolas como la respuesta a una supuesta "desnacionalización" maquinada, supuestamente, por el "Estado colonial" franquista a través de la llegada masiva de inmigrantes. Así lo formuló Jose Luis Álvarez Emparantza dentro de la organización ETA y así lo hizo, en su arrabal intelectual, Federico Krutwig, cuya obra ("Vasconia: estudio dialéctico de una nacionalidad", 1963) fue celebrada por la organización y definió buena parte del relato patriótico que ETA terminó adoptando como discurso legitimador. En una de sus diatribas a favor de la violencia revolucionaria, Krutwig había afirmado que era "una obligación (...) oponerse a la desnacionalización aunque para ello haya que emplear la revolución, el terrorismo y la guerra". La violencia fue adoptada, pues, como un instrumento nacionalizador tanto o más que revolucionario ${ }^{48}$.

La primera etapa de "renacionalización" buscó imponer en el espacio público la nueva memoria "compartida" y depurar el paisaje de símbolos que pudieran cuestionarla en tanto que "tradición nacional" 49 . La memoria participa en la construcción nacional del paisaje y determina, especialmente, la conversión de éste en un receptáculo simbólico del ayer en el hoy de la nación ${ }^{50}$. En junio de 1959, miembros de una autodenominada "Resistencia vasca" tacharon las inscripciones de los caídos locales colocadas en el Sagrado Corazón de Jesús de Bilbao y los monumentos consagrados a estos en Getxo, Baracaldo y Sestao; en abril de 1963, aparecieron pintadas con las siglas de ETA en el Sagrado Corazón de Jesús. Finalmente, en 1967, la organización puso en marcha más de un centenar de acciones violentas en otros tantos municipios de Vizcaya y Guipúzcoa dirigidas contra las placas que recordaban a los vascos caidos por Dios y por España ${ }^{51}$. Sobre el sentido que tenían estas prácticas para quienes las llevaron a cabo, uno de ellos ha recordado: "romper una lápida (para lo que resultaba suficiente una bola de hierro, alguien con la fuerza suficiente para arrojarla y una persona para vigilar) desencadenaba un proceso político que considerábamos concienciador porque inmediatamente el cura denunciaba el atentado pero también la parcialidad de que en la lápida figuraran solo la mitad de los muertos en una contienda civil" 52 .

Este antiguo militante ponía el ejemplo de Mondragón, donde la lápida fue destruida en dos ocasiones, por dos miembros de la ETA de entonces, naturales de esa localidad $^{53}$. La negativa del párroco a apadrinar la nueva placa conllevó un agrio enfrentamiento entre el Consejo Presbiterial y las autoridades provinciales, así como

48 FERNÁNDEZ, Gaizka y LÓPEZ, Raúl: Sangre, votos, manifestaciones: ETA y el nacionalismo vasco radical, 1958-2011, Madrid, Tecnos, 2012, pp. 53-54, 265, 255 y 271.

49 HOBSBAWM, Eric: "Introduction: Inventing Traditions", en Eric Hobsbawm y Terence Ranger (eds.), The Invention of Tradition, Cambridge/NY, Cambridge UP, 1992 (1983), pp. 1-14.

50 CASTIÑEIRA, Ángel: "Naciones imaginadas", pp. 54-55.

$51 A B C, 6$ diciembre 1970. LANDA, Carmelo: "Bilbao, 4 de enero de 1937, p. 107. Recuentos periódicos de estas acciones aparecen en los informes que los servicios de inteligencia de la policía cursaban al Gobierno Civil (Fondo del Archivo Histórico del Gobierno Civil de Vizcaya, depositado en el Dpto. de Historia Contemporánea de la UPV/EHU, Partes informativos trimestrales y Boletines informativos semanales, 19661970).

52 ONAINDIA, Mario: El precio de la libertad. Memorias (1948-1977), Madrid, Espasa, 2001, pp. 260261

53 BARROSO, Anabella: Sacerdotes bajo la atenta mirada del régimen franquista. Los conflictos sociopolíticos de la Iglesia vasca de 1960 a 1975, Bilbao, DDB, 1995, pp. 207-208. 
la invasión del pueblo por centenares de falangistas y requetés con motivo de la festividad en recuerdo de los caídos, cuya celebración provincial se trasladó a ella con ánimo de "resacralizar" un lugar de memoria patria que había sido "desacralizado". En este contexto se promovieron "misas de desagravio" que buscaban volver a purificar estos símbolos. Sin embargo, este programa de "ocupación" del paisaje "nacional" impulsado por las autoridades locales reflejó un escaso eco popular. Y es que la mayoría de las lápidas no volvieron a levantarse de nuevo o bien, cuando lo hicieron, el ritual de desagravio tuvo lugar ante una audiencia cada vez más mermada, lo que reflejó una clara falta de sintonía entre la política nacionalizadora "desde arriba" y su recepción "desde abajo". La razón es obvia: la Iglesia y la comunidad tradicionalista (los pilares locales del régimen que hubieran podido movilizar las masas) atravesaban un periodo de aguda crisis interna.

La Iglesia local se encontraba sumamente afectada por las consecuencias que el Vaticano II generó en su discurso pastoral, y no era para menos: "el Concilio fue el acta de defunción del nacionalcatolicismo como idea y como proyecto político (...). La defensa de los derechos humanos y políticos, la libertad religiosa o el pluralismo no encajaban con los postulados del modelo nacionalcatólico abrazado por el régimen" ${ }^{54}$. A ello se sumó el conflicto cultural entre la generación más joven, afín a estos presupuestos y encargada de catequizar los cambios conciliares, y la de la guerra civil (a su vez dividida entre un sector integrista y otro, más ancho, socialcatólico, que había apostado por una despolitización de sus acciones pastorales ${ }^{55}$. Ésta ruptura tuvo su dimensión patriótica, pues la nueva generación se implicó activamente en el proceso de "renacionalización" vasca. En los informes secretos policiales se aprecia la preocupación por las acciones de un "clero separatista" desafiante. Estas afectaban (como no podía ser menos) al programa renacionalizador del "nuevo Estado". Un ejemplo fue la actitud (claramente acordada) de coadjutores y miembros de parroquias locales vizcaínas y guipuzcoanas de retirar la bandera española del interior de sus iglesias parroquiales, bajo el argumento de "despolitizar" estos espacios, así como su rechazo a celebrar misas en recuerdo de los caídos o a reconstruir sus lápidas ${ }^{56}$.

Al compás en que los lugares de memoria nacional eran despiezados, la parroquia, el principal espacio de la nacionalización franquista, comenzaba a desintegrarse $y$, con ella, esa esfera local en la que el "nuevo Estado" había conseguido fijar su idea de nación. Mientras, la comunidad política que se había reproducido en ella, el tradicionalismo católico, había entrado en crisis, con una nueva generación que apostaba nada menos que por reubicar su "tradición" en la extrema izquierda marxista de la mano del "carlismo autogestionario" 57.

A principios de los setenta ETA prosiguió la destrucción de los lugares de memoria del franquismo local, una vez se había reforzado gracias al Juicio de Burgos. Su recuperación explica la mayor capacidad destructiva de sus acciones. Ya no fueron solo lápidas sino los propios monumentos a los caídos los que fueron volados mediante cargas explosivas. Tal fue el caso de la Cruz de los Caídos del Monte de Lemona y

\footnotetext{
54 LOUZAO, Joseba: “Nación y catolicismo en la España contemporánea...”, p. 85.

55 Idem, pp. 86-87.

56 BARROSO, Anabella: Sacerdotes bajo la atenta mirada ... pp. 202-214.

57 MOLINA, Fernando: "De la historia a la memoria"... pp. 190-191.
} 
del monumento a los caídos de Zeanuri, en Vizcaya; o el del monumento a los caídos de Tolosa y el busto en memoria de Juan Tellería (autor del "Cara al sol") en Zegama. A tal punto llegó la desesperación de las autoridades locales que en 1972 se fundó, a instancias de la diputación provincial, una asociación guipuzcoana para "la defensa y preservación de los monumentos a los muertos por la patria". Su objetivo fue programar los actos de desagravio y reconstrucción de los monumentos destruidos ${ }^{58}$. Y es que el ritual de desagravio patriótico reunía cada vez menos público local, por lo que su diseño ceremonial dependía de la puesta en marcha de autobuses de tradicionalistas y falangistas provenientes de toda la geografía vasca y alrededores. Esto fue lo que ocurrió durante la inauguración del nuevo busto a Juan Tellería en Zegama. En esta localidad guipuzcoana se reunieron, con ocasión de este acto, alcaldes y jefes locales del Movimiento, representaciones de los consejos locales y ayuntamientos de toda la provincia, hermandades de excombatientes, y demás delegaciones y organizaciones del Movimiento ${ }^{59}$.

Sin embargo, pese a que este cambio en la gestión de la movilización mejoró la programación de estos ceremoniales, la desorientación de esta comunidad política en crisis era total. Así lo reflejó el Consejo del Movimiento de Tolosa durante la preparación del acto de desagravio y reparación de la Cruz de los caídos que había sido dinamitada en esta localidad. En su convocatoria pública mostró un discurso dubitativo, en el que los patrones guerreros tradicionales se mezclaban con vagas apelaciones a los vencidos: "En los solemnes funerales que todos los años se celebran en esta basílica por el eterno descanso de los caídos de nuestra provincia, un grupo de guipuzcoanos rezamos por todos ellos y nunca preguntamos ni quien es el que reza ni por qué reza. Lo hacemos por todos ellos sin discriminación alguna. Hace algunos años que aprendimos a respetar el abrazo de nuestros muertos. Por eso, queremos expresar nuestro deseo de que, bajo esa cruz y esa bandera, en el monumento a los muertos de nuestra Cruzada que vamos a reconstruir figuren los nombres de todos los muertos de Tolosa entre 1936 y 1939 por la España que todos anhelamos"60.

El nuevo recuerdo institucional entraba en contradicción con una comunidad política y un régimen que habían hecho de una victoria bélica teñida de escatología católica la trama narrativa fundamental de su discurso de nación. De ahí que la alusión a la Cruzada casara con dificultad con el afán por recordar a "todos" los muertos y no solo a aquellos que habían legitimado, con su "martirio", la dictadura. Esta apuesta por un nuevo recuerdo compartido carecía, además, del fundamento cívico que le pudiera dotar de sentido político. A partir de 1976, iniciada la transición democrática, la mayoría de lápidas y monumentos que no habían sido volados por ETA fueron desapareciendo junto a las asociaciones creadas para perpetuar su memoria. En julio de 1976 el monumento a los caídos de Bilbao fue volado por ETA y sus restos fueron desmantelados en mitad del desinterés general, lo mismo que en pocos años ocurrió con el conjunto del callejero franquista ${ }^{61}$.

\footnotetext{
58 Informaciones, 3 y 4 abril 1972, 17 junio 1972, 13 julio 1973.

59 Informaciones, 18 abril 1972.

60 Informaciones, 14 abril 1972.

61 El País, 1 agosto 1976; LANDA, Carmelo: "Bilbao, 4 de enero de 1937”..., pp. 107-109.
} 


\section{El aniquilamiento de su memoria viva}

La violencia tiene una función pedagógica esencial. Facilita la agrupación de los individuos en bloques supuestamente homogéneos, separándolos entre puros e impuros y, consiguientemente, patriotas y "traidores". Cuando un discurso como el del nacionalismo vasco, obsesionado desde sus orígenes con fijar una frontera étnica entre lo propio y lo extraño, se dota de un repertorio narrativo y, sobre todo, de una acción colectiva de signo violento, esta función pedagógica adquiere un papel fundamental en la práctica del proyecto nacionalizador. Mario Onaindia, militante etarra a finales de los sesenta, recuerda que "no nos sentíamos pedagogos. No creíamos que teníamos que enseñar al pueblo algo concreto que sólo sabíamos nosotros, sino que la violencia desencadenaba un proceso en el que la gente aprendía por sus propios medios" "2. Sin embargo, toda violencia es un ejercicio de pedagogía que permitirá a la "gente" aprender. Pero no por "sus propios medios", sino guiados por una violencia que podía o no afectarles según cómo se posicionaran ante ella en el espacio público.

En 1968, ETA había decidido, en base a su particular memoria patriótica, construir un enemigo a base de destruirlo. Un enemigo cuya eliminación dotaba de sentido a la nación que pretendía regenerar. Se ha subrayado el contexto internacional que alimentó esta opción por la violencia, racionalizada en la conocida estrategia de acción-represión-acción ${ }^{63}$. Pero no creo que se haya reflexionado lo suficiente cómo esta estrategia pudo ser una adaptación lógica de la memoria patriótica que se había construido en las décadas pasadas en el seno de la comunidad nacionalista. La celebración de los caídos propios fue canalizada mediante tempranos rituales conmemorativos (Gudari Eguna, Eusko Gudariak, honras funerarias de activistas de ETA en las iglesias) y, pocos años después, terminó ocupando el espacio callejero en forma de pintadas o carteles. Todo fue nutrido por una narrativa (de nación) que celebraba la violencia pasada como celebraba (o disculpaba, en su nombre) la presente, señalando, de paso, a sus potenciales destinatarios. Ésta fue la cultura subyacente a la práctica de la violencia que sería adoptada como referente de identidad por una parte sustancial de la comunidad abertzale.

La violencia, por tanto, no sólo fue impulsada por una determinada cultura política marxista-leninista, revolucionaria y anticolonial que se encargó de construir el enemigo en tanto instrumento del Estado colonial (policías, militares) o comunidad de traidores que contribuía, en su doble condición explotadora (de nación y de clase), a celebrar el antifascismo virginal del pueblo vasco (la "oligarquía vasca", la "burguesía monopolista") y su futura redención como "clase trabajadora". Fue, también, impulsada por una "política de la memoria", pues sus acciones y prácticas fueron guiadas por el "recuerdo compartido". Cuando se decidió el asesinato del enemigo, la definición de éste reprodujo los parámetros narrativos de la memoria abertzale. Así, los primeros seleccionados fueron los miembros de las fuerzas y cuerpos de seguridad. A su eliminación discrecional se añadieron preceptivos elementos patrióticos,

62 ONAINDIA, Mario: El precio de la libertad..., p. 261.

63 GARMENDIA, José María: "ETA: nacimiento, desarrollo y crisis (1959-1978)” y JAUREGUI, Gurutz: "ETA: orígenes y evolución ideológica y política", en Antonio Elorza (coord.), La historia de ETA, Madrid, Temas de Hoy, 2006, pp. 142-150 y 242-248. 
caso de las ikurriñas que ocultaban cargas explosivas y que mataron o mutilaron a decenas de guardias civiles y policías en el final de la dictadura y los inicios de la transición.

Por lo demás, cuando la destrucción de los lugares de memoria franquista comenzó a reducirse tuvo lugar la intensificación de una violencia "renacionalizadora" caracterizada por el asesinato ejemplarizante de aquellos que, biográficamente, representaban la memoria destruida. Este colectivo reunió a quienes habían desempeñado cargos públicos durante la dictadura; a los ciudadanos que manifestaron pública fidelidad a ésta y trataron de conservar sus últimos restos institucionales; así como a quienes se apuntaron a las nuevas organizaciones derechistas o ultraderechistas que reivindicaban su legado y que surgieron al compás del cambio político.

Este variado colectivo fue construido en esos años en torno a la categoría enajenadora de "fascismo", prefigurada por la narrativa abertzale del pasado, que había definido la guerra civil como una guerra entre los vascos y el "fascismo" invasor ${ }^{64}$. Desde 1978 esta identidad destinada a la destrucción recibió un nuevo aporte: militantes o simpatizantes de partidos como UCD o AP, que se convirtieron, también, en destinatarios preferentes de los atentados terroristas que una ETA desgajada en dos organizaciones y una tercera residual, los Comandados Autónomos Anticapitalistas, dirigieron periódicamente contra ciudadanos vascos. Entre 1978 y 1982 más de dos decenas de cargos públicos o simpatizantes de estos partidos fueron asesinados mediante acciones que tenían como objetivo anular opciones políticas cuya tradición era negada por la memoria abertzale. El resultado fue una desarticulación total de la opción política más reticente a asumir el imaginario político que fue conferido al proyecto estatutario ${ }^{65}$.

Un aporte final fue el de una variada gama de individuos que, categorizados como "chivatos", fueron seleccionados con criterios ejemplarizantes, acusados de no haber seguido las normas de comportamiento social que implicaban desde la estigmatización de la identidad española (y su repertorio simbólico) en el espacio público a la prohibición de cualquier crítica a las acciones terroristas, pasando por el aislamiento forzoso de los policías y guardias civiles que, despersonalizados en torno a otra categoría, la de "perros", constituyeron siempre el principal objetivo a eliminar.

Todos estos aportes (fundados en categorías interactivas, que se solapaban y asociaban, pues no definían otra cosa que la identidad del ejecutor y de su colaborador necesario) nutrieron la espiral de violencia que, entre 1968 y 1978, la ETA de la dictadura y las ETAs de la transición convirtieron en el instrumento más potente de renacionalización del espacio público. Esta violencia permeó la vida social mediante un repertorio de usos cotidianos que abarcó desde fiestas locales a manifestaciones políticas, pasando a impregnar las formas de ocio colectivo y la propia estética calle-

${ }^{64}$ DE PABLO, Santiago: "Guerra Civil”, en Santiago de Pablo y otros (coords.), Diccionario ilustrado de símbolos ..., pp. 444-467; NÚÑEZ SEIXAS, Xose Manoel: "Los nacionalistas vascos durante la Guerra Civil (1936-1939). Una cultura de guerra diferente", Historia Contemporánea, $\mathrm{n}^{\circ} 35$, vol. II (2007), pp. 582-590; AGUILAR, Paloma: "La guerra civil española en el discurso nacionalista vasco"..., pp. 121-154.

65 FERNÁNDEZ SEBASTIÁN, Javier: "La derecha escamoteada. Desvanecimiento y reaparición de un espacio político en el País Vasco, 1975-1995”, Leviatán, no 61 (1995), pp. 5-26. 
jera ${ }^{66}$. La violencia terrorista actuó como una "política de la venganza" que alcanzó su plena operatividad a partir de 1978, cuando afectó con mayor intensidad a los individuos identificados con la memoria estigmatizada. Esto contribuyó a difuminar aún más a un colectivo político, el franquista o posfranquista, en declive ideológico y en progresiva desconexión con las nuevas culturas políticas. De esa manera, la realidad social fue forzada a adaptarse a la peculiar memoria de la oposición a la dictadura, que negaba cualquier implicación de la sociedad vasca en el entramado político e institucional de la dictadura y en las causas que condujeron a su institucionalización durante la guerra civil.

El recorrido cronológico por los principales hechos que definieron esta última fase de la "política de la venganza" del nacionalismo vasco se inicia en el año 1975. Los principales lugares de memoria franquistas habían sido ya destruidos y los que quedaban comenzarían, en breve, a ser desmantelados. Fue en ese año cuando comenzó una segunda etapa del proyecto renacionalizador abertzale. La biografía colectiva que las lápidas de los caídos habían reflejado estaba representada, aún por entonces, por miles de simpatizantes de los principios ideológicos y el proyecto político de la dictadura. Y estos individuos recibieron una primera advertencia cuando ETA militar asesinó a un vecino de la localidad guipuzcoana de Itziar: Carlos Arguimberri. Su asesino le llamó "perro" antes de pegarle varios tiros en la cabeza sin dar tiempo a que parara el autobús que conducía.

Carlos había sido convertido en "víctima propiciatoria" por el nuevo nacionalismo que había arraigado en el espacio semipúblico de Itziar (parroquia, cuadrillas, asociaciones deportivas y culturales). Fue aislado socialmente, amenazado de forma anónima, atacado en sus negocios y, finalmente, asesinado. Él y su familia, de simpatías carlistas, habían desempeñado trabajos marginales en una comunidad rural, lo que facilitó el poder colocarlos fuera de la norma colectiva. Por lo demás, a medida que el carlismo había ido declinando sociológicamente, su lugar había sido ocupado por el nacionalismo vasco, que compartía con él una similar consideración de la identidad vasca y de su significado político. Este proceso de sustitución, al coincidir con la nueva estrategia liquidadora de ETA, significó una sentencia de muerte en diferido para Carlos.

Desde finales de los sesenta, en los mismos años en que las lápidas de los caídos eran reventadas a decenas en Guipúzcoa o Vizcaya, se había corrido el rumor de que era un chivato y, consiguientemente, un perro. En su proceso de expulsión de la condición de sujeto moral participó la propia Iglesia. Jóvenes de un grupo parroquial local habían realizado en 1972 (el mismo año en que el Consejo del movimiento de Tolosa había manifestado su ambigua posición respecto a qué pasado recordar) pintadas con el lema "Carlos hil" (muerte a Carlos). El pueblo mudó en silencio una vez fue asesinado y cuando se vio forzado a razonar su muerte públicamente lo hizo de forma similar a como había interpretado, en el pasado, la violencia institucional franquista: "estaba metido en política" ${ }^{67}$.

66 FERNÁNDEZ, Gaizka y LÓPEZ, Raúl: Sangre, votos y manifestaciones..., pp. 271-278.

67 ZULAIKA, Joseba: Basque Violence: Metaphor and Sacrament, Las Vegas/Reno, University or Nevada Press, 1988 (ed. española, 1989), pp. 74-87. 
Lo ocurrido a Carlos comenzó a reproducirse en una geografía rural y urbana en la que las listas de confidentes y "chivatos" se manejaban con ánimo coactivo e intimidatorio en compañía de amenazas veladas o públicas ${ }^{68}$. Una geografía en que las lápidas de los caídos habían sido sustituidas por carteles y pintadas que decoraban los muros y lonjas de cada pueblo, recordando a los militantes de ETA caídos, presos o "refugiados" en Francia. En esos espacios de memoria se advertía a vecinos de sus conductas o se les requería para que abandonasen la localidad. Este proceso de nacionalización "desde abajo" arraigó en las "escuelas sociales" fundadas por sacerdotes jóvenes, en las parroquias que estos dirigían y sus grupos de jóvenes católicos, en las organizaciones políticas y sindicales clandestinas que ocuparon con hábito o sin hábito, en las cuadrillas de amigos, en las familias, en las fiestas locales, en los clubs de montaña y de deporte, en las nuevas "ikastolas" legalizadas ${ }^{69}$.

Se trató de un proceso de "construcción de un pueblo" en el que ETA buscaba "despertar" a éste a la conciencia (supuestamente dormida) de ser una nación. Ese proceso de renacionalización llevó aparejada una política de la memoria que dictaminó qué había que recordar y qué era mejor olvidar. No había que recordar que muchos vecinos habían sido afectos a un franquismo considerado extraño en tanto que "fascismo español". Sí había que recordar que otros estaban presos o en la clandestinidad. Y ese recuerdo, como cualquier otro, estaba compuesto por "historias" que vinculaban los itinerarios y experiencias del individuo a la nación. Las mismas "historias de nacionalistas" que se habían contado desde la Guerra Civil en el marco de la comunidad abertzale ${ }^{70}$.

El camino abierto con Carlos fue recorrido especialmente a partir de 1978, cuando la violencia fue practicada a una escala masiva, permitiendo "acumular" cerca de tres centenares de asesinatos en una estrategia destinada a forzar al Estado a negociar el proyecto político del nacionalismo vasco radical. Ésta espiral incentivó a la población a apartarse de cualquier individuo susceptible de ser incorporado a las categorías que conducían a la destrucción ${ }^{71}$. Esta intensificación de la violencia mejoró su potencial nacionalizador, al dotar a esta de una cadencia repetitiva y redundante fundamental a la hora de conferirle una capacidad pedagógica que hasta entonces había sido muy limitada. Son estos los años en que puede hablarse de una activa renacionalización vasca ajena a los canales institucionales, que tomaba forma en el espacio público y semipúblico y que se fundaba, como la franquista, en la violencia política. Es por ello que se dotó de su mismo repertorio discursivo y que estuvo también arropada por una amplia masa social.

Cerca de sesenta ciudadanos vinculados a la dictadura o a partidos derechistas fueron asesinados por las dos ETAs, sustancialmente por la rama militar, entre los años

68 FERNÁNDEZ, Gaizka y LÓPEZ, Raúl:, Sangre, votos, manifestaciones..., pp. 271-272, 278-281. El arraigo local dela figura del "chivato" en HEIBERG, Marianne: The Making of the Basque Nation, Cambridge, Cambridge, 1989 (hay ed. española), pp. 149-150.

69 FERNÁNDEZ, Gaizka y LÓPEZ, Raúl:, Sangre, votos, manifestaciones..., p. 333.

70 CASTIÑEIRA, Ángel: "Naciones imaginadas", p. 46; JUARISTI, Jon: El bucle melancólico. Historias de nacionalistas vascos, Madrid, Espasa, 1996, pp. 17-34..

71 FERNÁNDEZ, Gaizka y LÓPEZ, Raúl:, Sangre, votos, manifestaciones..., pp. 278-280. 
1976 y 1980, la mayoría en pequeñas localidades ${ }^{72}$. Unos en tanto que encarnación de la "oligarquía", caso de Javier de Ybarra, secuestrado y asesinado de manera ritual en junio de 1977. Otros, por haberse significado por su fidelidad a la dictadura, caso de Esteban Beldarrain, teniente alcalde de Castillo-Elejabeitia, asesinado en marzo de 1978 y que se había hecho famoso por haber disparado contra una ikurriña que se izó en la plaza de su pueblo una vez la enseña fue legalizada. O el de Jose María Maderal Oleaga, Presidente de la Hermandad de Antiguos Caballeros Legionarios de Vizcaya, asesinado en marzo de 1979. Su hermano, Andrés Maderal, había fallecido en la guerra de Sidi-Ifni y contaba con una estatua en su Erandio natal, inaugurada en 1966 en memoria de su "heroico fallecimiento" en acción de guerra. La estatua era esporádicamente ensuciada con pintadas en las que se acusaba al "héroe" local de "asesino de vascos". Un año después del asesinato de Jose María, en agosto de 1980, en mitad de las fiestas de la localidad, fue arrojada a la ría del Nervión por los vecinos ${ }^{73}$.

A la par, se practicó una eliminación ejemplar de esos otros "fascistas" considerados como tales por vincularse a partidos derechistas no abertzales. Estos asesinatos tuvieron un componente patriótico fundamental. Vicente Zorita, militante de Alianza Popular de Santurce, fue asesinado por ETA militar en noviembre de 1980. Su asesinato incorporó una particular cadencia ritual. Fue secuestrado, torturado y asesinado con siete tiros en la cabeza. Su cuerpo fue abandonado en el portal de su casa. Su cráneo destrozado estaba tapado por un gorro de lana. Su boca había sido amordazada con una bandera española ${ }^{74}$. Dos años después, la misma organización asesinó en Getxo a otro simpatizante de Alianza Popular, Aberto López Jaureguizar. Como en el caso de Zorita había sido un individuo poco sensible a respetar los códigos de silencio y gestualidad del nuevo tiempo nacionalizador. Si Zorita había destacado por criticar públicamente a ETA y calificar de asesinos a sus miembros, López había ido más lejos: colocaba una bandera española con un crespón negro en su terraza cada vez que un policía o guardia civil eran asesinados ${ }^{75}$.

\section{Conclusión}

La evaluación del "éxito" nacionalizador franquista es objeto de disputa por los historiadores. Unos sancionan que "fracasó en sus objetivos", como constataría la persistencia de los nacionalismos subestatales y su reforzamiento en los últimos años del régimen, la crisis del nacionalismo español en la transición y la posición dubitativa

72 ORELLA, José Luis Orella: Los otros vascos: historia de un desencuentro, Bilbao, Grafite, 2003; MERINO, Antonio y CHAPA, Álvaro: Raices de libertad, Fundación Bilbao, Popular de Estudios Vascos, 2011.

73 La Vanguardia, 19 junio 1966 y 4 septiembre de 1968; El País, 23 junio 1977; Informaciones, 17 marzo 1978; El Correo Español, 17 marzo 1979.

74 El País, 16 noviembre 1980.

75 El País, 17 julio 1980. La intrahistoria de estos asesinatos en el documental Olvidados, dirigido por Iñaki Arteta en 2004 y en http://www.testimoniosvictimasterrorismo.com/asp/quicktime.asp?video=0479\&id datos $=479 \&$ nombre $=$ VICENTE. 
de las izquierdas españolas ante este ${ }^{76}$. Recientemente esta apreciación ha sido cuestionada mediante un manejo más complejo del concepto de "proceso de nacionalización". Así, la nacionalización franquista habría fracasado en su dimensión "autoritaria" pero no en su carácter "renacionalizador". Para ello se propone "diferenciar entre la efectividad de la nacionalización en el sentido más básico - transmisión de la idea de pertenencia a la nación española - y la efectividad de la nacionalización específicamente franquista - transmisión de los concretos contenidos asociados a los nacionalismos franquistas". Así, los mecanismos informales de nacionalización (esfera pública, cultura popular y de masas, festividades e identidades de signo subestatal) siguieron "saturados de españolidad" tanto en esos años como en los de la democracia. Algo parecido se ha defendido para las elites intelectuales e izquierdistas de la época ${ }^{77}$.

La trayectoria histórica vasca cuestiona este segundo posicionamiento. De nuevo el País Vasco "dinamita" (y el verbo es penosamente ilustrativo) cualquier consenso historiográfico acerca de los modos y formas de la nacionalización española, como ocurre con la evaluación de su dimensión trivial y cotidiana ${ }^{78}$. No creo fácil separar cualquier nación de su contenido ideológico y simbólico, y en este sentido la falta de sintonía de la nación española en tanto que "proyecto autoritario-totalitario" con una nueva generación de nativos e inmigrantes, fue esencial en los años sesenta y setenta a la hora de comprender por qué esta "audiencia" eligió la vasca y se dejó seducir por su narrativa, convirtiéndola en la hegemónica en el espacio público.

La nacionalización no puede pervivir únicamente en la esfera privada sino que precisa de un emplazamiento mínimo de sus discursos y prácticas simbólicas en el ámbito público y semipúblico. Desde los años setenta tuvo lugar en el País Vasco un progresivo abandono de la simbología española en ambos espacios, a la par que sus valedores fueron asesinados o forzados al silencio, la emigración o el exilio. Mientras, los inmigrantes instalados en estas tierras mostraron una activa absorción de los símbolos, ritos y mitos de la nueva cultura abertzale ${ }^{79}$. Estos dos hechos reflejan que, siquiera en este territorio, no se puede hablar de un éxito renacionalizador españolista desde el momento en que la cultura política que lo soportó entró en crisis generacional. A partir de entonces, este proyecto se vio sumido en una crisis cultural sobre la que incidió una violencia patriótica de signo expiatorio, en un sentido cualitativo (no, obviamente, cuantitativo) similar a lo que sufrió en la guerra e inmediata posguerra el españolismo republicano en estas tierras.

76 NÚÑEZ SEIXAS, Xose Manoel: "Nuevos y viejos nacionalistas: la cuestión territorial en el tardofranquismo, 1959-1975", Ayer, nº 68 (2007), p. 87.

77 Citas tomadas de FUERTES, Carlos: "La nación vivida”, p. 281 y ARCHILÉS, Ferrán: "Melancólico bucle. Narrativas de la nación fracasada e historiografía española contemporánea”, en Ismael Saz y Ferrán Archilés (eds.), Estudios sobre nacionalismo y nación en la España contemporánea, Zaragoza, Prensas Universitarias, 2011, p. 287.

78 MOLINA APARICIO, Fernando: "La nación desde abajo"..., pp. 47-48.

79 SHAFIR, Gerson: Inmigrants and Nationalists. Ethnic Conflict and Accommodation in Catalonia, the Basque Country, Latvia, and Estonia, Nueva York, State University of New York, 1995, pp. 19-27, 120-121; KASMIR, Sharryn: The Myth of Mondragon. Cooperatives, Politics, and Working-Class Life in a Basque Town, Nueva York, State University of New York, 1996, pp. 104-120 (hay ed. española). 
El hecho de que el proceso renacionalizador fuera similar en ambos casos, centrado en la imposición de la nación mediante un discurso excluyente que alentó la violencia como práctica política, hizo que la dinámica de sustitución de un proyecto por otro fuera brutal. La guerra civil, en un caso, y la estrategia terrorista, en el otro, pueden considerarse contextos afines de oportunidades políticas que permitieron la movilización y homogeneización de las masas en torno a dos proyectos de nación alimentados por el "deber de intolerancia" respecto del otro. En ambos casos, estos proyectos fueron sustentados por "comunidades de violencia", es decir, comunidades políticas que se dotaron de una identidad fundada en repertorios narrativos agresivos, revanchistas y victimistas acerca del pasado, permeados de sacralidad y que favorecían la conversión de una parte importante de sus miembros en ejecutores y colaboradores entusiastas de la violencia política.

El escritor Bernardo Atxaga recuerda que, en 1964, "tenía trece años cuando escuché por primera vez la palabra Euzkadi. (...) Mi compañero de pupitre (...) declaró: Nik bizia emango nikek Euzkadiren alde. Es decir: 'yo daría la vida por Euzkadi'. (...) Gu ez gaituk espainolak, gu euskaldunak gaituk, añadió el compañero (...). 'Nosotros no somos españoles, nosotros somos vascos' (...). Lo ocurrido aquel día me marcó profundamente, (...). No fui un caso aislado, sino uno más de los muchísimos que se dieron en aquella época (...). Todos supieron de la existencia de un país oculto, y a todos les emocionó la noticia cuando, al igual que lo había hecho mi compañero de escuela, los encargados de transmitirla se mostraron tristes y soñadores: tristes al principio de la conversación, cuando se trataba de hablar de la guerra perdida y del pueblo sojuzgado por un dictador obsesionado con destruir todo lo vasco; soñadores después, cuando se explicaba el ideal, que no era otro que la liberación de Euzkadi (...). Sin embargo, por muy emotiva que nos resultara, por muy enamorados que estuviéramos de ella, la idea era en gran parte falsa. (...) De vez en cuando, el azar nos presentaba un caso que no encajaba en nuestra precaria ideología, pero nosotros no reparábamos en ello. Recuerdo por ejemplo que un campesino, hablando de una de las primeras víctimas de la guerra, un conocido carlista, dijo: Banderan dena bilduta ekarri ziaten, 'lo trajeron totalmente envuelto en la bandera'. Nosotros pensamos que se refería a la verde, roja y blanca. (...) No hubo dudas ni averiguaciones, y nuestra idea - nuestro sentimiento-, de lo que era Euzkadi se mantuvo incólume" ${ }^{80}$. El editor Xabier Mendiguren también recuerda que, diez años después de estos hechos, "en la escuela, en la catequesis, nos decían que matar estaba mal, pero eso valía para cuando uno mataba a otro, no sin embargo para el caso en que uno de ETA mataba a un policía: eso era la guerra, y nosotros ya sabíamos, porque lo teníamos visto en mil películas, que en la guerra el bueno mata al malo, porque se lo merece y porque tiene que ser así" $"$.

En ese intervalo de tiempo, entre 1964 y 1975, el espacio semipúblico y privado vasco vivió un proceso de renacionalización acelerada en el que la memoria fue reutilizada como fuente de alimentación de la violencia de ETA. De esa manera esta or-

80 ATXAGA, Bernardo: “De Euzkadi a Euskadi”, en Josetxo Beriain y Ramón Fernández (eds.), La cuestión vasca. Claves de un conflicto cultural y político, Barcelona, Anthropos, 1999, pp. 64-66 (cursivas mías, salvo las que indican las traducciones al castellano del euskera).

81 MENDIGUREN, Xabier: Gure barrioa 1975, San Sebastián, Elkar, 1998, p. 26. 
ganización y su comunidad de violencia fijaron en el espacio público de la transición democrática qué recordar y cómo ubicarlo en la memoria colectiva. Los carlistas se convirtieron en gudaris, fosilizándose el pasado en ese continuo histórico de enfrentamiento sagrado con España que hoy día se denomina "conflicto vasco". Y la violencia fue esencial a la hora de dictar qué recordar y qué olvidar. El asesinato de los últimos carlistas o falangistas, así como de todos aquellos que manifestaran público disentimiento con el recuerdo compartido, favoreció el silencio y el olvido acerca del pasado incómodo.

En los años que median entre el recuerdo de Atxaga y el de Mendiguren se produjo una "intersección de procesos nacionales" que fue evocada por José Ramón Recalde en un artículo que publicó pocos años después. Su concepción de tal intersección se fundaba en presupuestos teóricos modernizadores, en una metodología marxista y en la narrativa historiográfica de la "nación (española) fracasada". Sobre todo ello acababa de escribir un voluminoso libro teórico cuya aplicación práctica al caso vasco planteaba en este articulito ${ }^{82}$. Su tesis era que, dado que los nacionalismos creaban las naciones, tanto España como Euskadi eran naciones con aspiraciones unitarias fracasadas. En el primer caso, por el diseño centralista del Estado, representado de forma paradigmática por el franquismo; en el segundo, por su diseño cultural esencialista, reflejado en el proyecto político de ETA. La intersección de ambos procesos históricos había generado un conflicto entre nacionalismos que reivindicaban una similar política "asimilacionista" que imposibilitaba "resolver de forma armónica la construcción de la nación vasca dentro de la comunidad nacional española" ${ }^{83}$. Su compromiso con tal proyecto "armonizador" le había empujado a la cárcel en tiempos del franquismo y le llevaría, años después de publicar este artículo, a sufrir un atentado terrorista que estuvo a punto de acabar con su vida. El título y contenido de su articulito siempre me cautivó por su didactismo acerca del contexto histórico que permitió que se sucedieran en tierra vasca dos proyectos nacionales de signo depredador. Su experiencia biográfica de victimización por ambos constituye, de hecho, el mejor testimonio de la dimensión fúnebre que ambos procesos de nacionalización han tenido. Sobre ella he tratado de reflexionar en estas páginas. Lo que puedan tener de interés va a él dedicado.

82 RECALDE, Jose Ramón: "Estudio del conflicto español-vasco. Intersección de procesos nacionales", Estudios de Historia Social, $\mathrm{n}^{\circ}$ 28-29, (1984) pp. 77-84; La construcción de las naciones, Madrid, Siglo XXI, 1982. El influjo de esta obra en una nueva generación intelectual y académica crítica con los planteamientos políticos del nacionalismo vasco en ONAINDIA, Mario: Guía para orientarse ..., p. 233.

83 RECALDE, Jose Ramón: La construcción de las naciones..., pp. 412-415 y 448-449. 